UDC: 602.44:546.284

COBISS.SR-ID: 227890188

Original research paper

Acta Agriculturae Serbica, Vol. XXI, 41 (2016); 47-55

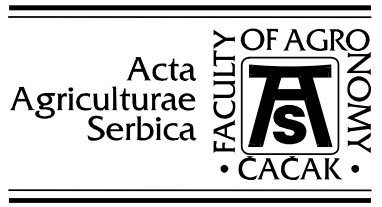

\title{
Synthesis and characterization of porous silica particles for bioseparation application
}

\author{
Milan P. Nikolić ${ }^{*}$, Lenka Ribić-Zelenović ${ }^{1}$, Tomislav Trišović ${ }^{1}$, \\ Slobodanka Stanojević-Nikolić ${ }^{1}$ \\ ${ }^{1}$ University of Kragujevac, Faculty of Agronomy, Cara Dusana 34, 32000 \\ Čačak, Republic of Serbia \\ *corresponding author (e-mail address: milanik@kg.ac.rs)
}

\begin{abstract}
Two types of silica particles were synthesized by the sol-gel process. The first type of silica particles was synthesized by neutralization of a highly basic sodium silicate solution. The obtained particles were polydispersed with irregular shapes and a mesoporous structure. The second type of silica particles was prepared by hydrolysis and condensation of tetraethylortosilicate (TEOS). The obtained particles were spherical and monodispersed with a microporous structure. Multimodal size distribution was characteristic of the silica particles obtained from the sodium silicate solution with a particle size distribution between 0.2 and $6 \mu \mathrm{m}$. On the other hand, the silica particles obtained from TEOS had a unimodal size distribution with an average particle size of about $0.5 \mu \mathrm{m}$. The physical adsorption of Candida rugosa lipase onto the obtained silica particles was investigated at $\mathrm{pH}=7$. The silica particles prepared from TEOS had the lowest adsorption efficiency (2\%) while those prepared from the highly basic sodium silicate solution had the highest adsorption efficiency (50\%). The isoelectric point of silica particles and Candida rugosa lipase was 2.5 and 2.4, respectively, which suggests that van der Waals' forces probably play the major role in the process of binding lipase into mesoporous silica when physical adsorption was involved at $\mathrm{pH} 7$.

Key words: silica, mesoporous, microporous, lipase, adsorption.
\end{abstract}

Received: 20.05.2016; Accepted: 28.09.2016 


\section{Introduction}

Silica particles have been widely used due to their chemical stability, biocompatibility, non-toxicity and relatively easy synthesis, enabling adjustable size, morphology and porosity. The main advantages of mesoporous silica materials are high surface area and high total pore volume with narrow pore size distribution (Moelans et al. 2005). These properties make silica particles attractive for many applications, such as "nanocarriers" for the delivery of drugs and other cargos to cells (Tarn et al. 2013), the templates for the synthesis of various materials (Ryoo et al. 1999), enzyme immobilization and biocatalysis (Moelans et al. 2005, Serra et al. 2008), bioseparation (Liu et al. 2012), biosensors (Thörn et al. 2013), sorption of organic and inorganic pollutants (Tao et al. 2012), etc. There are many techniques for the synthesis of silica particles but the most popular one is the sol-gel synthesis (Brinker and Scherer, 1990). Two methods related to sol-gel synthesis are usually used for the preparation of silica particles. The first is the Stöber method (Stöber et al. 1968) which is based on hydrolysis and condensation of a highly reactive silicon-alkoxide precursor (tetraethylorthosilicate) under basic conditions. The second sol-gel method for the preparation of silica particles is based on acidic neutralization of a highly basic sodium silicate solution (Han et al. 2003). Silica particles obtained by the Stöber method have a microporous structure with an average pore size below 2 $\mathrm{nm}$. To prepare mesoporous silica particles with an average pore size between 2 and $50 \mathrm{~nm}$, pore swelling agents are used to allow formation of mesopores and, thus, calcination or extraction is performed to remove templates from the structure (Bagshaw 1995, Han et al. 2003).

Mesoporous silica particles obtained from sodium silicate solution can also be prepared without templates (Filipović et al. 2009). This synthesis method is much less expensive and simpler than the template synthesis method.

In this work, two types of silica particles with different structures, functionalities and sizes were synthesized by the Stöber method and acidic neutralization of sodium silicate solution, respectively, without using pore forming agents. The effect of silica particle type on adsorption efficiency of lipase from Candida rugosa was also investigated. The investigation is important

as it might help in finding optimal silica material which can find potential application in bioseparation.

\section{Materials and methods}

Silica particles prepared by the Stöber method (sample $T_{S}$ ) were synthesized by hydrolysis and condensation of tetraethylortosilicate (TEOS), dissolved in anhydrous ethanol, with distilled water under basic conditions $\left(25 \% \mathrm{NH}_{3}\right.$, Merck $)$ 
(Stöber et al. 1968). The sample was prepared using a molar ratio TEOS: $\mathrm{H}_{2} \mathrm{O}: \mathrm{NH}_{4} \mathrm{OH}=1: 40: 4$ and a TEOS concentration of $0.25 \mathrm{~mol} / \mathrm{l}$. After feeding, the product suspension was continuously stirred at room temperature for $1 \mathrm{~h}$. The white precipitated powder was centrifuged and washed with distilled water until the effluent was free of $\mathrm{NH}_{4}$ groups, and finally dried at $120^{\circ} \mathrm{C}$ for 1 day.

Mesoporous silica particles (sample $S_{S}$ ) were prepared from highly basic sodium silicate solution (Water glass, Alumina Factory-Birač, Zvornik, Republic of Srpska) having a $\mathrm{SiO}_{2} / \mathrm{Na}_{2} \mathrm{O}$ molar ratio of $3.5 \mathrm{~mol} / \mathrm{mol}$ and a $\mathrm{SiO}_{2}$ concentration of $55 \mathrm{~g} / 1$ (Filipović et al. 2009). Sulfuric acid was slowly added into well stirred sodium silicate solutions at $90^{\circ} \mathrm{C}$ to precipitate silica particles. During the reaction, the color of the aqueous sodium silicate solution changed from colorless to milky while the viscosity of the solution increased. Finally, the reaction was stopped when the viscosity of the solution became very high, after which the precipitate was washed with distilled water, separated from the liquid phase by centrifugation and finally dried at $120^{\circ} \mathrm{C}$ for 1 day.

The influence of the type of silica particles on the physical adsorption of the enzyme lipase obtained from Candida rugosa was also investigated. In all batch kinetic adsorption experiments, $20 \mathrm{mg}$ of silica supports (samples $T_{S}$ and $S_{S}$ ) and $4 \mathrm{~mL}$ of lipase solution at a concentration of $0.4 \mathrm{mg} / \mathrm{ml}$ in $0.1 \mathrm{M}$ phosphate buffer, $\mathrm{pH} 7.0$, were added into a flask and stirred magnetically. After 20 minutes of mixing, the reaction mixture was centrifuged at $13000 \times \mathrm{g}$ for $4 \mathrm{~min}$ and the supernatant was used for the determination of the amount of lipase in the solution. The concentration of lipase was measured by the Bradford method (Bradford 1976) with BSA as a standard at $595 \mathrm{~nm}$.

The adsorption efficiency (\%) of lipase was calculated using the equation (Amuda et al. 2007):

$$
\text { Adsorption efficiency }=\frac{C_{i}-C_{f}}{C_{i}} \times 100
$$

where $C_{i}$ and $C_{f}$ are the initial and final equilibrium concentration of the lipase, respectively.

The obtained silica particles were also characterized by DLS and SEM. The particle size was measured by dynamic light scattering (Zetasizer Nano ZS, Malvern Instruments, Malvern, United Kingdom) and the zeta potential of particles was determined by phase analysis light scattering and mixed mode measurement (Zetasizer Nano ZS with MPT-2 Autotitrator Malvern Instruments, Malvern, United Kingdom). The size and morphology of the particles were examined using a scanning electron microscope (JEOL JSM 6460 LV, Tokyo, Japan) operating at $20 \mathrm{kV}$. Pore size distribution (according to the BJH method) was measured by low temperature nitrogen adsorption using a Quantachrom Autosorb-3B instrument. 


\section{Results and Discussion}

Figures 1a and 1b show SEM micrographs of silica particles prepared from sodium silicate (sample $S_{S}$ ) and TEOS (sample $T_{S}$ ), respectively. In contrast to the silica particles prepared from TEOS with an average particle size of $\sim 0.5 \mu \mathrm{m}$, the aggregated silica particles prepared from sodium silicate do not have spherical shape and unimodal size distribution.

a)

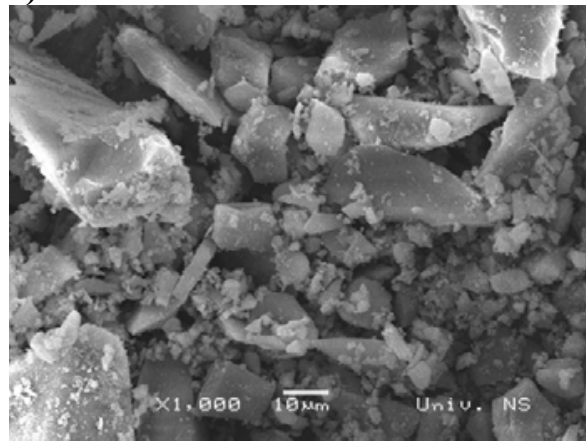

b)

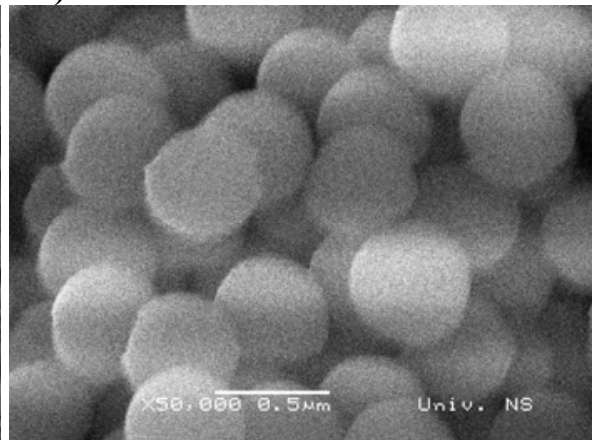

Figure 1. SEM micrographs of silica particles prepared from sodium silicate solution (a) and silica particles prepared from TEOS (b).

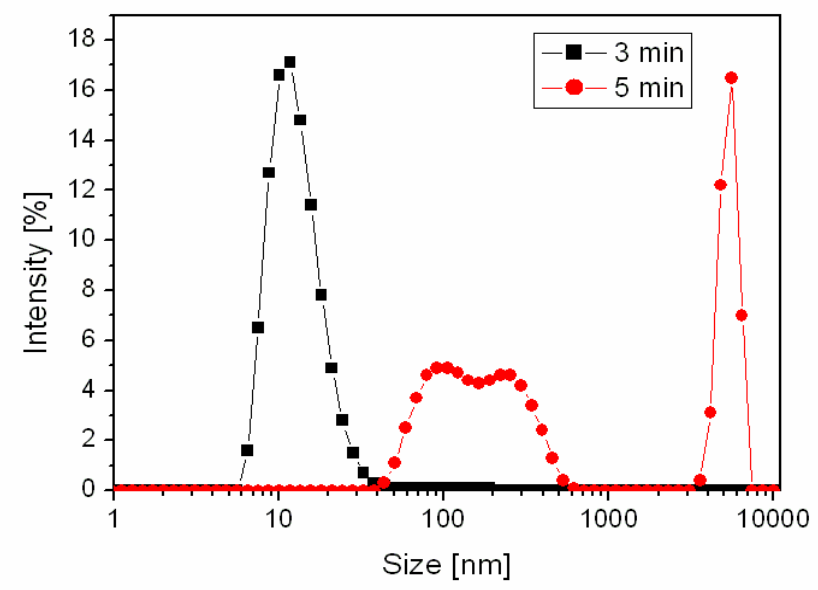

Figure 2. Effect of reaction time on the size of silica particles obtained by acidic neutralization of highly basic sodium silicate solution $\left(\mathrm{SiO}_{2}=77 \mathrm{~g} / \mathrm{l}, \mathrm{M}=3.5\right)$ at $90^{\circ} \mathrm{C}$. 
The mechanism of formation of silica particles obtained by neutralization of sodium silicate solution has been studied during the reaction by the DLS method. Figure 2 shows particle size distributions of the samples taken from the reaction vessel during the reaction at two different time intervals. The reaction vessel initially contained sodium silicate solution $\left(\mathrm{SiO}_{2}=55 \mathrm{~g} / 1, \mathrm{M}=3.5\right)$ at $90^{\circ} \mathrm{C}$. Sulphuric acid was slowly added into the stirred vessel so that the rate of neutralization was constant throughout the reaction. After a reaction time of 3 minutes, there is a unimodal particle size distribution showing a peak at $15 \mathrm{~nm}$ which refers to silica nanoparticles generated by neutralization of sodium silicate solution. As the reaction proceeds, intensive aggregation begins, and is represented by the particle size distribution obtained after 5 minutes. It can be seen that there is a trimodal particle size distribution which shows two low intensity peaks at 100 and $270 \mathrm{~nm}$, and a high-intensity peak at $5350 \mathrm{~nm}$.

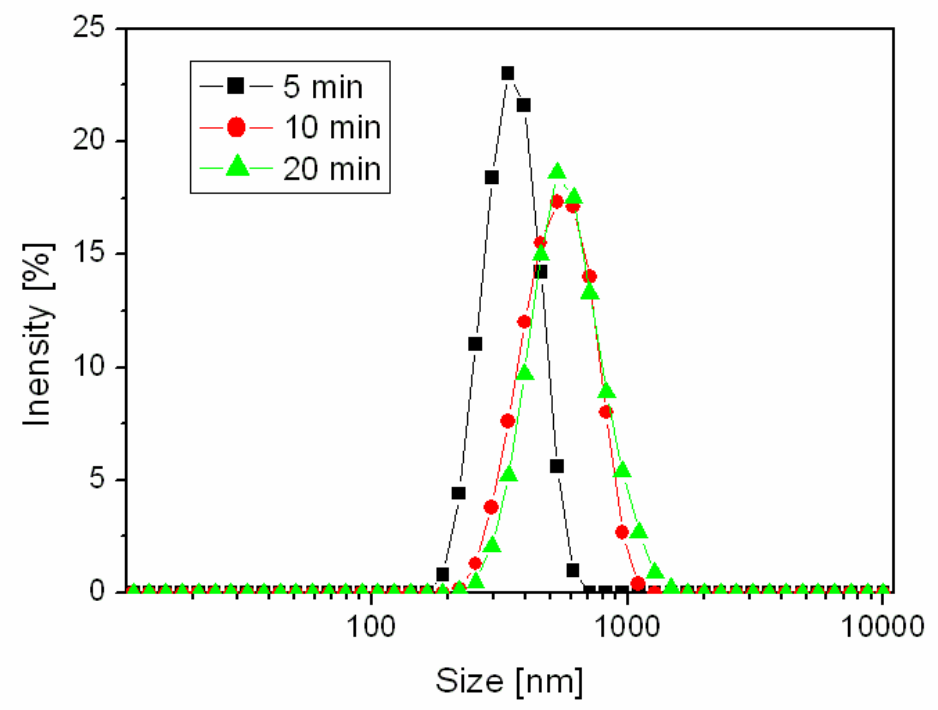

Figure 3. Effect of reaction time on the size of silica particles obtained by hydrolysis and condensation of TEOS.

Figure 3 shows particle size distributions of the samples taken from the reaction vessel during the hydrolysis and condensation of TEOS. After a reaction time of 5 minutes, there is a unimodal particle size distribution showing a peak at $350 \mathrm{~nm}$ which refers to silica particles obtained by the hydrolysis and condensation of TEOS. The average size of particles obtained after 10 and 20 minutes was 550 and $600 \mathrm{~nm}$, respectively, which suggests that the further prolongation of reaction time led to an increase in particle size.

The average pore size of the silica particles obtained from the sodium silicate solution (sample $S_{S}$ ) and those obtained from TEOS is 11 and $2 \mathrm{~nm}$, respectively. 
It can therefore be concluded that silica particles prepared from a highly basic sodium silicate solution have a mesoporous structure. On the other hand, silica particles prepared from TEOS have a microporous structure.

The adsorption of an enzyme onto silica materials (samples $S s$ and $T_{S}$ ) was also investigated. The adsorption efficiency of lipase adsorbed on these supports is shown in Table 1. The results show that mesoporous silica particles (sample $S s$ ) have the highest lipase adsorption efficiency of about $50 \%$. The lipase adsorption efficiency for microporous silica particles (sample $T_{S}$ ) dropped dramatically, and was only $2 \%$. Lipase has a diameter of around $4.5 \mathrm{~nm}$ (Gustafsson, 2011); therefore, it can be assumed that the enzyme molecule can penetrate into the pore of the silica material if the pore size is larger than $4.5 \mathrm{~nm}$. The sample $S_{S}$ has high adsorption efficiency due to its mesoporous structure with a large total pore volume and an average pore size of $11 \mathrm{~nm}$. The sample $T_{S}$ has very low adsorption efficiency due to its microporous structure that prevents the enzyme from penetrating into the pores of this material. In this case, the enzyme was only adsorbed on the external surface of $\mathrm{T}_{\mathrm{S}}$ silica particles.

Table 1. The adsorption efficiencies of lipase adsorbed onto silica particles (samples $S_{S}$ and $T_{S}$ )

\begin{tabular}{|c|c|c|}
\hline Sample notation & $S_{S}$ & $T_{S}$ \\
\hline $\begin{array}{c}\text { The adsorption } \\
\text { efficiency [\%] }\end{array}$ & 50 & 2 \\
\hline
\end{tabular}

To determine the nature of the physical adsorption of lipase onto the surface of silica particles, isoelectric points of both mesoporous silica particles and lipase were determined. As shown in Fig. 4, the isoelectric point of mesoporous silica particles (sample $S_{S}$ ) and Candida rugosa lipase was 2.5 and 2.4, respectively. Since the adsorption of the enzyme onto silica particles was performed in phosphate buffer at $\mathrm{pH} 7.0$, it may be concluded that both silica particles and Candida rugosa lipase were negatively charged at $\mathrm{pH}$ 7. Thus, there should be no attractive electrostatic interactions between them. This also suggests that van der Waals' forces probably play the major role in the process of binding lipase into mesoporous silica when physical adsorption was involved. 


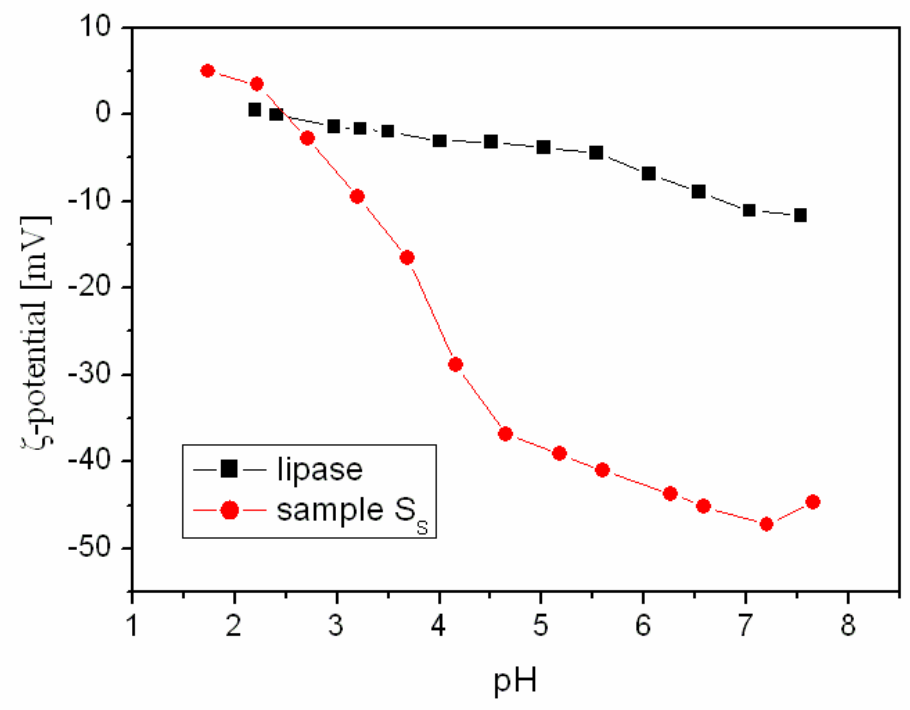

Figure 4. Isoelectric titration graphs of silica particles (sample Ss) and lipase.

\section{Conclusion}

Two types of silica particles were synthesized using two synthetic procedures: hydrolysis and condensation of tetraethylorthosilicate (TEOS) and neutralization of sodium silicate solution. Monodispersed and spherical silica particles (average size $\sim 0.5 \mu \mathrm{m}$ ) prepared by the hydrolysis and condensation of tetraethylorthosilicate have a microporous structure (the average pore size below $2 \mathrm{~nm}$ ). Silica particles prepared by the neutralization of sodium silicate solution have irregular shapes and a mesoporous structure (the average pore size of 11 $\mathrm{nm})$. The average pore size of silica particles prepared from TEOS was lower than lipase diameter which resulted in very low lipase adsorption efficiency of only $2 \%$. The average pore size of silica particles prepared from sodium silicate solution was larger than the enzyme diameter which allowed immobilization of enzymes inside pores of material with the adsorption efficiency of $50 \%$. It was found that both silica particles and Candida rugosa lipase were negatively charged at $\mathrm{pH} 7$, indicating that van der Waals' interactions may predominate in the mechanism of adsorption of lipase into silica particles.

\section{Acknowledgements:}

This work was financially supported by the Ministry of Education, Science and Technological Development of the Republic of Serbia under Project Ref. No. III45021. 


\section{References}

Amuda O.S., Giwa A.A., Bello I.A. (2007): Removal of heavy metal from industrial wastewater using modified activated coconut shell carbon. Biochem Eng J, 36:174181.

Bagshaw S.A., Prouzet E., Pinnavaia T.J. (1995): Templating of mesoporous molecular sieves by nonionic polyethylene oxide surfactants. Science, 269: 1242-1244.

Bradford M. (1976): A rapid and sensitive method for the quantitation of microgram quantities of protein utilizing the principle of protein-dye binding. Anal Biochem, 72: 248-254.

Brinker C.J., Scherer G.W. (1990): Sol-gel science, the physics and chemistry of sol-gel processing. Academic Press, Boston.

Filipović R., Obrenović Z., Stijepović I., Nikolić Lj.M., Srdić V.V. (2009): Synthesis of mesoporous silica particles with controlled pore structure. Ceram Inter, 35: 33473353.

Gustafsson H., Thörn C., Holmberg K. (2011): A Comparison of lipase and trypsin encapsulated in mesoporous materials with varying pore sizes and $\mathrm{pH}$ conditions. Colloids Surf B, 87: 464-471.

Han S., Houa W., Danga W., Xua J., Hub J., Lic D. (2003): Synthesis of rod-like mesoporous silica using mixed surfactants of cetyltrimethylammonium bromide and cetyltrimethylammonium chloride as templates. Mater Lett, 57: 4520-4524.

Liu J., Wang B., Hartono S.B., Liu T., Kantharidis P., Middelberg A.P.J., Lu G.Q., He L., Qiao S.Z. (2012): Magnetic silica spheres with large nanopores for nucleic acid adsorption and cellular uptake. Biomaterials, 33: 970-978.

Moelans D., Cool P., Baeyens J., Vansant E.F. (2005): Using mesoporous silica materials to immobilise biocatalysis-enzymes. Catal Commun, 6: 307-311.

Ryoo R, Joo S.H., Jun S. (1999): Synthesis of highly ordered carbon molecular sieves via template-mediated structural transformation. J Phys Chem B, 103: 7743-7746.

Serra E., Mayoral A., Sakamoto Y., Blanco R.M., Diaz I. (2008): Immobilization of lipase in ordered mesoporous materials: effect of textural and structural parameters. Micropor Mesopor Mater, 114: 201-213.

Stöber W., Fink A., Bohn E. (1968): Controlled growth of mesoporous silica spheres in the micron size range. J Colloid Interface Sci, $26: 62$.

Tao S., Wang C., Ma W., Wu S., Meng C. (2012): Designed multifunctionalized magnetic mesoporous microsphere for sequential sorption of organic and inorganic pollutants. Micropor Mesopor Mater, 147: 295-301.

Tarn D., Ashley C.E., Xue M., Carnes E.C., Zink J.I., Brinker C.J. (2013): Mesoporous silica nanoparticle nanocarriers: biofunctionality and bio-compatibility. Acc Chem Res, 46: 792-801.

Thörn C., Gustafsson H., Olsson L. (2013): QCM-D as a method for monitoring enzyme immobilization in mesoporous silica particles. Micropor Mesopor Mater, 176: 71-77. 


\title{
SINTEZA I KARAKTERIZACIJA POROZNIH SILIKA ČESTICA ZA PRIMENU U BIOSEPARACIJAMA
}

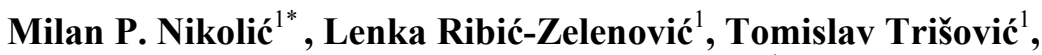 \\ Slobodanka Stanojević-Nikolić ${ }^{1}$ \\ (1) University of Kragujevac, Faculty of Agronomy, Cara Dusana 34, 32000 \\ Čačak, Republic of Serbia \\ *corresponding author (e-mail address: milanik@kg.ac.rs)
}

\begin{abstract}
Rezime
Dve vrste silika čestica sintetisane su sol-gel procesom. Prva vrsta čestica sintetisana je neutralizacijom jako baznog rastvora natrijum silikata. Dobijene čestice bile su polidisperzne, nepravilnog oblika i mezoporozne strukture. Druga vrsta silika čestica dobijena je hidrolizom i kondenzacijom tetraetil-ortosilikata (TEOS). Dobijene čestice bile su sferične i monodisperzne sa mikroporoznom strukturom. Multimodalna distribucija dimenzija je karakteristična za silika čestice dobijene iz rastvora natrijum silikata, i dimenzije ovih čestica kretale su se u intervalu između 0,2 i $6 \mu \mathrm{m}$. Silika čestice dobijene iz TEOS imale su unimodalnu distribuciju dimenzija sa srednjim prečnikom čestica oko $0,5 \mu \mathrm{m}$. Ispitivana je i fizička adsorpcija lipaze iz Candida rugosa na silika česticama pri $\mathrm{pH}=7$. Silika čestice dobijene iz TEOS imale su veoma nisku efikasnost adsorpcije, od samo $2 \%$, dok su silika čestice dobijene iz jako baznog rastvora natrijum silikata imale visoku efikasnost adsorpcije od 50\%. Izoelektrična tačka silika čestica i lipaze iz Candida rugosa iznosila je 2,5 odnosno 2,4, iz čega se može zaključiti da, pri fizičkoj adsorpciji izvršenoj na $\mathrm{pH}$ 7, van der Waals privlačne sile doprinose vezivanju lipaze na silika česticama.
\end{abstract}

Ključne reči: silika, mezoporozan, mikroporozan, lipaza, adsorpcija. 